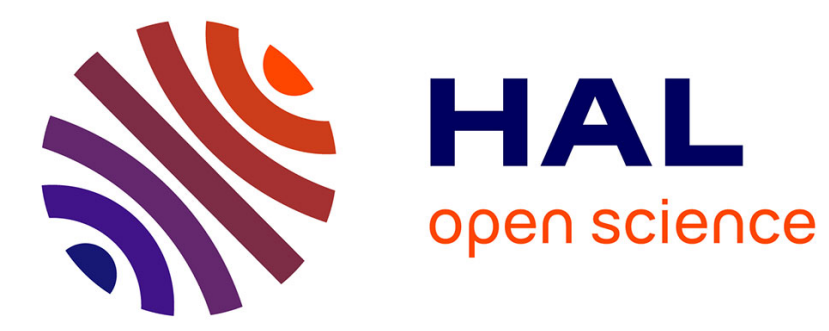

\title{
The buoyancy convection during directional solidification of AlZn eutectic
}

\author{
M. Prazák, M. Procio, S. Holecek
}

\section{To cite this version:}

M. Prazák, M. Procio, S. Holecek. The buoyancy convection during directional solidification of AlZn eutectic. Journal de Physique IV Proceedings, 1993, 03 (C7), pp.C7-855-C7-858. 10.1051/jp4:19937134 . jpa-00251754

\section{HAL Id: jpa-00251754 https://hal.science/jpa-00251754}

Submitted on 1 Jan 1993

HAL is a multi-disciplinary open access archive for the deposit and dissemination of scientific research documents, whether they are published or not. The documents may come from teaching and research institutions in France or abroad, or from public or private research centers.
L'archive ouverte pluridisciplinaire HAL, est destinée au dépôt et à la diffusion de documents scientifiques de niveau recherche, publiés ou non, émanant des établissements d'enseignement et de recherche français ou étrangers, des laboratoires publics ou privés. 


\title{
The buoyancy convection during directional solidification of AlZn eutectic
}

\author{
M. PRAŽÁK, M. PROCIO and S. HOLEČEK
}

Institute of Chemical Technology, Department of Metals and Corrosion Engineering, Technická 5, 16628 Prague 6, Czech Republic

\begin{abstract}
A study has been made of the effect of buoyancy convection during the directional solidification of AlZn eutectic alloy, Experiments have been conducted using a Bridgman-Stockbarger arrangement with the furnace moving along the specimen. The apparatus rotated around the horizontal axis, which made it possible to carry out measurements at different angles $B$ contained by the gravity and temperature gradient vectors in the specimen.

The anisotropy of both the linear thermal expansion coefficient $a$ and the hardness $H K$ measured by the Knoop method has been studied. The dilatation measurements confirmed the expected anisotropy of the linear thermal expansion of directionally solidified specimens. The values of HK correspond with the lamellar spacing measured in the metallographic study.
\end{abstract}

\section{Introduction}

One of the trends in current materials research is the research of the force effects of gravity on the crystallization of metals. Studies into the mechanism of flow are rather difficult in non-transparent metallic liquids, inasmuch as the application of optical techniques is precluded. The technique which is most frequently used for this purpose is the measurement of temperature gradients and temperature fluctuations.

An important factor affecting the growth of a crystal from the melt is the buoyancy convection caused by temperature and concentration gradients. The intensity of the development of buoyancy convection depends on the physical properties of the melt, the ampoule used, the temperature gradient along the specimen and the orientation of the specimen in this field of gravity [1].

Recent measurements in fully molten specimens show that an axially located insert (used for the temperature measurement) serves as a passive agitator which increases the transfer of heat and 
mass in the specimen in dependence on the angle $B$ contained by the temperature gradient in specimen and the gravity vector $[2,3]$. Various types of melt convection was also studied. The amplitudes of temperature fluctuations in the melt do not give explicit informa$t i o n$ on the total effective intensity of convection, but only on the level of the instability of convection [4].

In addition, the buoyancy convection depends significantly on the size and shape of the ampoule. For cylindrical ampoules the ratio of the ampoule height $h$ to its diameter $d$ is a decisive factor, so called characteristic specimen ratio. Critical values of the Rayleigh number in dependence on $h / d$ characteristic for the boundary between various types of convection (1amelar - periodic - turbulent) were determined for the AlZn eutectic [5].

\section{Experiment}

AlZn eutectic system has been used for experiments. The Bridgman-Stockbarger arrangement of the experiment was used. The specimens were enclosed in cylindrical graphite ampoules (inner diameter 11 or $22 \mathrm{~mm}$ ) with stainless steel inserts (outer diameter $2 \mathrm{~mm}$ ) located in the axis of the ampoule and/or near the wall of the cylindrical ampoule.

Temperature was measured with $\mathrm{NiCr}-\mathrm{Ni}$ jacketed thermocouples (1 $\mathrm{mm}$ or $0.5 \mathrm{~mm}$ diameter). The apparatus rotated around its horizontal axis; thus the angle $B$ contained by the axial temperature gradient vector in the specimen $G$ and the gravity vector $g$ could be changed.

For dilatometric measurements the specimens were prepared by different growth velocities $v\left(0.2-1000 \mu \mathrm{m} / \mathrm{s}, B=180^{\circ}\right)$. These specimens were used for the hardness measurement by the knoop method ( $4.91 \mathrm{~N}, 30 \mathrm{sec}$.$) and for metallographic evaluation of the$ dependence of the lamellar spacing on the crystallization velocity $v$. Hardness HK was measured on the cross section of specimens both parallel and perpendicular to the lamellae.

\section{Results and Discussion}

The dilatation measurements confirmed the anisotropy of the linear thermal expansion a of directionally solidified samples of Al-Zn eutectic, figure 1. The values of the coefficient a in radial direction was obtained as the average of two values measured in two perpendicular directions. It can be seen that the growth velocity $1000 \mathrm{\mu m} / \mathrm{s}$ is too high to form a good unidirectional structure having significant difference between a values in axial and radial directions.

Figure 2 shows the dependence of the lamellar spacing on the crystalization velocity $\left(B=0^{\circ}\right.$ and $\left.180^{\circ}\right)$. The difference of both values for the lowest crystallization velocity $0.2 \mu \mathrm{m} / \mathrm{s}$ could be caused by the influence of intensive time dependent buoyancy convection by solidification of the sample for the angle $B=0^{\circ}$. Because of the very small growth velocity the crystallization interface is strongly affected by the temperature fluctuations. 


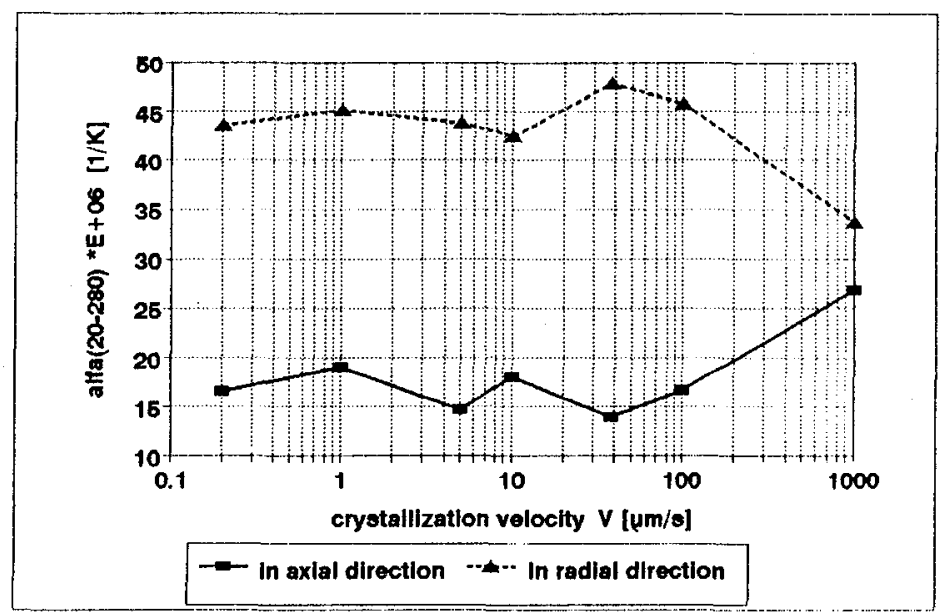

Figure 1. Linear thermal expansion coefficient a versus crystallization velocity $V, B=180^{\circ}$.

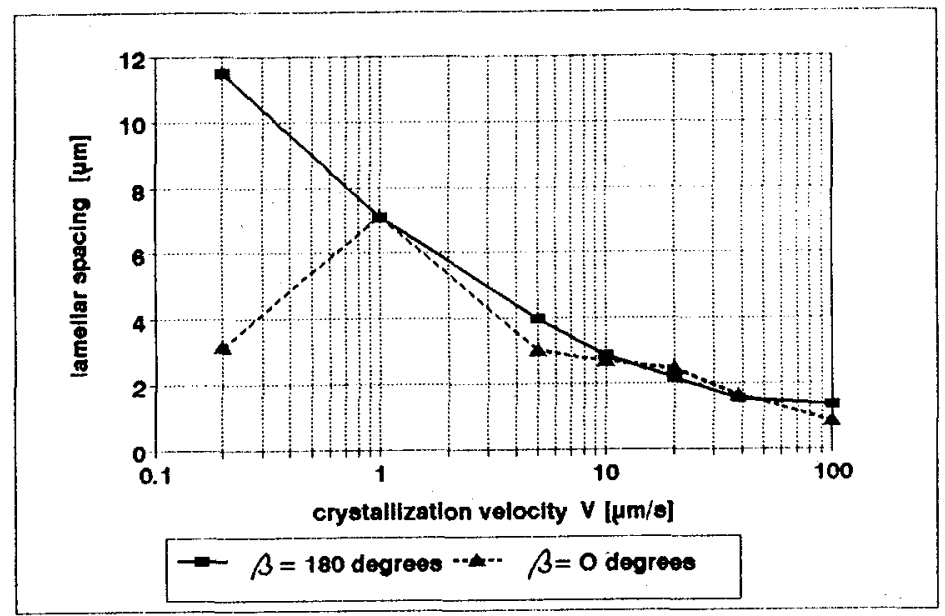

Figure 2. Lamellar spacing versus crystallization velocity $v$. 


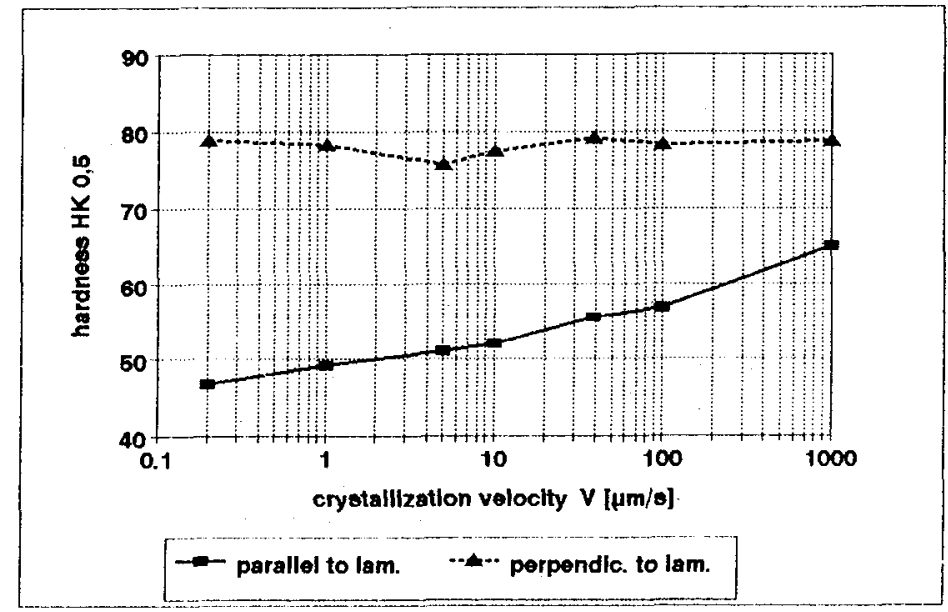

Figure 3. Knoop hardness HK versus crystallization velocity $v$.

\begin{abstract}
The measurement of the hardness at the direction parallel to the lamellae (figure 3 ) shows an increasing in dependence on increasing of the growth velocity which correspondent to an decrea\$ sing of the lamellar spacing. Hardness HK measured in perpendicular direction seems to be relatively independent on the crystallization velocity.
\end{abstract}

\title{
Conclusions
}

The dilatometric measurements showed that the crystallization velocity over $100 \mu \mathrm{m} / \mathrm{s}$ significantly decreases the quality of structure unidirectionality. It could be said that the dilatometry is a suitable method for the determination of the level of unidirectionality of the $A 1 Z n$ eutectic in dependence on the proces parameters; in this case on crystallization velocity. The hardness measurement confirmed that the mechanical properties of directionally solidified specimens depend on the lamelar spacing.

\section{References}

[1] SAHM P.R., Convective transport and instability phenomena, G. Braun, Karlsruhe 1982

[2] TUCEK V., HOLECEK S., KUBICEK L., BARTA C., Cryst.Res.Technol. 21 (1986) 10

[3] HOLECEK S., PROCIO M., PRAZAK M., KUBICEK L., Cryst.Res.Techno1. 26 (1991) 4

[4] HOLECEK S., PROCIO M., PRAZAK M., KUBICEK L., Cryst.Res.Technol. 26 (1991) 5

[5] TUCEK V., HOLECEK S., KUBICEK L., Cryst.Res.Techno1.22 (1987) 6 